\title{
Artikel
}

\section{Grensoverschrijdend contracteren binnen de Europese Unie: de erkenning en tenuitvoerlegging van beslissingen in burgerlijke en handelszaken gebaseerd op het beginsel van wederzijds vertrouwen, getoetst aan het EVRM}

Mr. dr. J.M. Emaus*

\section{Inleiding 1}

Voor een rechtsgeding tussen contractspartijen afkomstig uit twee of meer EU-lidstaten ${ }^{2}$ is in de Brussel I Verordening herschikking (hierna: de Brussel I Herschikking; in de literatuur ook: EEX-Verordening herschikking) bepaald welke rechter in de zaak bevoegd is, en ook op welke wijze de erkenning en tenuitvoerlegging

Mr. dr. J.M. Emaus is universitair docent aan het Molengraaff Instituut voor Privaatrecht van de Universiteit Utrecht en als onderzoeker verbonden aan het Utrecht Centre for Accountability and Liability (Ucall) en het Utrecht Centre for Regulation and Enforcement in Europe (Renforce).

1. Zie voor een meer wetenschappelijke beschouwing over de interactie tussen wederzijds vertrouwen, wederzijdse erkenning en fundamentele rechten in het internationaal privaatrecht in relatie tot de aspiraties van de Europese Unie ten aanzien van contractuele relaties: J.M. Emaus, 'The Interaction Between Mutual Trust, Mutual Recognition and Fundamental Rights in Private International Law in Relation to the European Union's Aspirations relating to Contractual Relations', European Papers 2017, te verschijnen.

2. Denemarken uitgezonderd. Zie over de positie van Denemarken meer uitgebreid overweging 41 in de considerans van de verordening. van de door het gerecht van herkomst ${ }^{3}$ gegeven 'beslissing' ${ }^{4}$ dient te geschieden. Sinds de inwerkingtreding van de Brussel I Herschikking geldt dat voor de erkenning en tenuitvoerlegging van een beslissing uitgesproken in een andere lidstaat geen procedure meer nodig is. ${ }^{5}$ Erkenning en tenuitvoerlegging gebeurt, anders gezegd, automatisch. Die automatische erkenning en tenuitvoerlegging is gebaseerd op het Unierechtelijke beginsel van 'wederzijds vertrouwen in de rechtsbedeling in de Unie' en moet worden gezien in het licht van het doel van de verordening, namelijk om 'een ruimte van vrijheid, veiligheid en recht te handhaven en te ontwikkelen en de toegang tot de rechter te vergemakkelij-

3. Volgens art. 2 aanhef en sub f Brussel I Herschikking: 'het gerecht dat de beslissing heeft gegeven waarvan de erkenning wordt ingeroepen of de ten uitvoerlegging wordt gevorderd'

4. Volgens art. 2 aanhef en sub a Brussel I Herschikking: 'elke door een gerecht van een lidstaat gegeven beslissing, ongeacht de daaraan gegeven benaming, zoals arrest, vonnis, beschikking of rechterlijk dwangbevel, alsmede de vaststelling van het bedrag van de proceskosten door de griffier'.

5. Zie over Brussel I Herschikking: A. Dickinson \& E. Lein (eds.), The Brussels I Regulation Recast, Oxford: Oxford University Press 2015; U. Magnus \& P. Mankowski, Brussels Ibis Regulation (European commentaries on private international law), Keulen: Otto Schmidt 2016; V. Lazić \& S. Stuij, Brussels Ibis Regulation. Changes and Challenges of the Renewed Procedural Scheme, Den Haag: T.M.C. Asser Press 2016. 
ken' ${ }^{6}$ Ter bescherming van de belangen van 'belanghebbende partijen' is op verzoek van een van deze partijen weigering van de erkenning mogelijk als die geslaagd een beroep op een van de weigeringsgronden kan doen. Tot de weigeringsgronden behoort onder meer - en wordt het meest ingeroepen voor de nationale rechter, zo blijkt uit een onderzoek door Hess, Pfeiffer en Schlosser $^{7}$ - het niet tijdig of niet juist betekenen of meedelen van de inleidende stukken aan de gedaagde, zodat die niet in staat is zich te verweren. ${ }^{8}$ Het is de balans tussen de eenvoudige erkenning en tenuitvoerlegging enerzijds en de weigering om dat te doen vanwege dringende redenen anderzijds die in de recente zaak Avotinšs/Letland centraal stond. ${ }^{9}$ Voor het Europees Hof voor de Rechten van de Mens (EHRM) werd geklaagd over de houdbaarheid van de afweging door de Letse rechter in het licht van artikel 6 van het Europees Verdrag voor de rechten van de mens (EVRM): het recht op een eerlijk proces. De zaak Avotiņš/Letland is zowel aanleiding voor als centraal thema in deze bijdrage.

Ofschoon feiten als in de zaak Avotinšr/Letland zich niet dagelijks aan de Nederlandse contractenrechtjurist presenteren, ${ }^{10}$ mag deze uitspraak van de Grote Kamer van het EHRM hem mijns inziens toch niet ontgaan. Het EHRM heeft daarin belangrijke overwegingen gegeven met betrekking tot de verhouding tussen het EVRM en het Unierecht en over de houdbaarheid van de erkenning en tenuitvoerlegging op grond van Unierecht in het licht van artikel 6 EVRM. Het is voor het eerst dat het EHRM zich uitspreekt over de samenloop van Unierecht en het EVRM sinds het verschijnen van Opinion 2/13 van het Hof van Justitie van de Europese Unie over de verenigbaarheid van het ontwerpakkoord inzake de toetreding van de Europese Unie tot het EVRM, waarin het Hof van Justitie (kritisch) stilstaat bij de verhouding tussen het EVRM en de Europese Unie. ${ }^{11}$ En het is ook de eerste keer dat er voor het EHRM is geklaagd over de verzekering van het recht op een eerlijk proces in relatie tot wederzijdse erkenning op grond van Unierecht. ${ }^{12}$

Deze bijdrage start in paragraaf 2 met een introductie van het Unierechtelijke kader (gevormd door de Brussel I Verordening en de Brussel I Herschikking) voor de erkenning en tenuitvoerlegging van beslissingen in burgerlijke en handelszaken. In paragraaf 3 worden kort de

6. Overweging 3 considerans Brussel I Herschikking.

7. B. Hess, Th. Pfeiffer \& P. Schlosser, Report on the Application of Regulation Brussels I in the Member States, Study JLS/C4/2005/03, 2007, p. 239.

8. Art. 45 Brussel I Herschikking.

9. EHRM (Grote Kamer) 23 mei 2016, 17502/07 (Avotinš/Letland). Zie over de uitspraak onder meer G. Biagioni, Avotinš v. Latvia. The Uneasy Balance Between Mutual Recognition of Judgments and Protection of Fundamental Rights, European Papers 2016, p. 579-596.

10. Zie voor een korte uiteenzetting van die feiten par. 3

11. HvJ EU 18 december 2014, Avis 2/13. Zie ook in reactie daarop (kritisch) de (dan) voorzitter van het EHRM, Dean Spielmann: D. Spielmann, Foreword, in: European Court of Human Rights, Annual Report 2014, Straatsburg 2015, p. 6.

12. Zie de constatering door het Hof: EHRM (Grote Kamer) 23 mei 2016, 17502/07, par. 98 (Avotiņš/Letland). feiten uiteengezet die in de zaak Avotinšs/Letland centraal stonden. Daarop volgt in paragraaf 4 een bespreking van de rechtsgang in die zaak en de klacht voor het EHRM. In paragraaf 4 wordt ook uiteengezet wat de overwegingen van de Grote Kamer van het EHRM ten aanzien van de klacht waren. In paragraaf 5 wordt vervolgens de relevantie van de uitspraak voor de Nederlandse rechtspraktijk besproken. De bijdrage sluit in paragraaf 6 af met een conclusie.

Het is, tot slot, van belang voorop te stellen dat de Brussel I Herschikking op 10 januari 2015 in werking is getreden en dat die verordening in de zaak Avotiňš/Letland aldus nog niet van toepassing was. Het is haar voorganger, de Brussel I Verordening (in de literatuur ook: EEX-Verordening), die hier centraal stond. Dat doet er niet aan af, ik zal dat hierna nog verder toelichten, dat de overwegingen die in de zaak worden gegeven volgens mij niet anders zouden zijn als de Brussel I Herschikking zou zijn toegepast. Op grond van de Brussel I Verordening, die tegenwoordig overigens nog geldt voor procedures die aanhangig zijn gemaakt vóór de inwerkingtreding van de Brussel I Herschikking, ${ }^{13}$ was en is een zogenoemde exequaturprocedure vereist om tot erkenning en tenuitvoerlegging van een in een andere lidstaat gegeven beslissing te komen. Geen automatische erkenning en tenuitvoerlegging dus. Een belangrijke overweging om de uitspraak (ook) in het licht van de nieuwe verordening te bespreken, is om in deze bijdrage tevens (kort) te informeren over de erkenning en tenuitvoerlegging van beslissingen zoals die op grond van de Brussel I Herschikking dient plaats te vinden.

\section{Het Unierechtelijke kader voor de erkenning en tenuitvoerlegging van beslissingen in burgerlijke en handelszaken}

\subsection{De erkenning en tenuitvoerlegging van in een} andere EU-lidstaat uitgesproken beslissingen De erkenning en tenuitvoerlegging door EU-lidstaten van beslissingen die in een andere EU-lidstaat zijn uitgesproken, is door de Europese Unie geregeld in de Brussel I Herschikking die, zoals gezegd, per 10 januari 2015 de Brussel I Verordening heeft vervangen en van toepassing is op procedures die vanaf dat moment aanhangig zijn gemaakt. Het uitgangspunt in de nieuwe regeling is automatische erkenning en tenuitvoerlegging, geregeld in artikel 36 e.v. Brussel I Herschikking. Dat is anders dan in de Brussel I Verordening, waarin voor de erkenning en tenuitvoerlegging een zogenoemde exequaturprocedure is voorgeschreven. Die procedure houdt in dat een verzoek tot erkenning en tenuitvoerleg-

13. Zie: art. 66 Brussel I Herschikking. 
ging dient te worden gericht aan een gerechtelijke instantie of tot de uitvoerbaarverklaring bevoegde autoriteit in de aangezochte lidstaat. Het is belangrijk daarbij te constateren dat tijdens die procedure de gronden voor weigering, die in de volgende paragrafen verder worden toegelicht, niet ambtshalve mogen worden getoetst. ${ }^{14}$ Dat betekent dat voor de toepassing van de weigeringsgronden dus zowel onder de Brussel I Verordening als onder de Brussel I Herschikking door belanghebbenden daarop een beroep moet worden gedaan.

De exequaturprocedure zou, aldus de Europese Commissie in het voorstel voor de nieuwe verordening, 'nog steeds een belemmering [zijn] voor het vrije verkeer van beslissingen, die voor de betrokken partijen onnodige kosten en vertraging met zich brengt en ondernemingen en burgers ervan weerhoudt de mogelijkheden van de interne markt optimaal te benutten'. ${ }^{15}$ Sterker: de Europese Commissie noemde deze constatering in 2010 een van de vier grootste gebreken van de Brussel I Verordening. De afschaffing van de exequaturprocedure werd verder gemotiveerd met de vaststelling dat 'de justitiële samenwerking en het vertrouwen tussen de lidstaten een niveau [hebben] bereikt dat het mogelijk maakt te komen tot een eenvoudiger, goedkoper en meer automatisch systeem voor het vrije verkeer van beslissingen, waarbij de bestaande formaliteiten tussen de lidstaten worden afgeschaft'. ${ }^{16}$

Het is evenwel de vraag of het 'wederzijdse vertrouwen in de rechtsbedeling in de Unie' zo sterk is als door de Europese Commissie wordt verondersteld. Weller wijst in dit verband op een Eurobarometer uit 2013 over 'Justice in the EU', waaruit blijkt dat EU-burgers menen dat er grote verschillen bestaan tussen nationale rechtssystemen als het gaat om kwaliteit, efficiëntie en onafhankelijkheid. ${ }^{17}$ Weller, kritisch, noemt het veronderstelde vertrouwen 'quite demanding' en constateert dat de Europese Commissie op het terrein van het strafrecht voorzichtiger te werk gaat. ${ }^{18}$ Hij stelt dat de kracht van het beginsel van wederzijds vertrouwen om de wederzijdse erkenning te rechtvaardigen beperkt is en dat de grenzen ervan moeten worden gerespecteerd; 'using mutual trust as a legal fiction does not work'. ${ }^{19}$ Daarbij verdient opmerking dat in het Europees Parlement op het moment onderzoek wordt verricht naar de haalbaar-

14. Overweging 17 considerans Brussel I Verordening. Zie ook M.I. Hazelhorst \& X.E. Kramer, Afschaffing van het exequatur in Brussel I: daadwerkelijke verbetering of politiek gebaar?, TCR 2013/2, p. 38.

15. Europese Commissie, Voorstel voor een verordening van het Europees Parlement en de Raad betreffende de rechterlijke bevoegdheid, de erkenning en de tenuitvoerlegging van beslissingen in burgerlijke en handelszaken (Herschikking), COM/2010/748, p. 3.

16. Europese Commissie, Voorstel voor een verordening van het Europees Parlement en de Raad betreffende de rechterlijke bevoegdheid, de erkenning en de tenuitvoerlegging van beslissingen in burgerlijke en handelszaken (Herschikking), COM/2010/748, p. 6.

17. M. Weller, Mutual trust: in search of the future of European Union private international law, Journal of Private International Law 2015, p. 66. Zie Europese Commissie, Flash Eurobarometer 385. Justice in the EU, 2013.

18. Weller 2015, p. 85.

19. Weller 2015, p. 85. Onder verwijzing naar: N. Knauer, Legal Fictions and Juristic Truth, St Thomas Law Review 2010/1, p. 19. heid en mogelijkheid tot het streven naar 'common minimum standards for civil procedure in the European Union to strengthen mutual trust'. In dat kader is reeds een drietal concrete opties voor het bereiken van harmonisatie van regels van burgerlijk procesrecht gepresenteerd, alsook onderzoek verricht naar de bevoegdheidsgrondslag van de Europese Unie om op dit gebied (regelgevend) op te treden. $^{20}$

Wat van het werkelijke wederzijdse vertrouwen en de inspanningen van de Europese Unie om dat te versterken verder ook zij, aan de Brussel I Herschikking ligt aldus, zo blijkt uit de preambule, de doelstelling ten grondslag een 'ruimte van vrijheid, veiligheid en recht te handhaven en te ontwikkelen'. ${ }^{21} \mathrm{Om}$ die doelstelling te verwezenlijken is ingezet op 'justitiële samenwerking in burgerlijke zaken met grensoverschrijdende gevolgen'. ${ }^{22}$ Een leidend beginsel daarbij is dat van wederzijds vertrouwen, dat werkt als grondslag voor de automatische erkenning en tenuitvoerlegging van in een andere EU-lidstaat uitgesproken beslissingen. ${ }^{23}$

\subsection{Gronden voor weigering}

\subsubsection{Weigeringsgronden in de Brussel I Verordening en de Brussel I Herschikking}

De automatische erkenning en tenuitvoerlegging van beslissingen is niet absoluut. Terwijl onder de Brussel I Verordening met een beroep op één of meer van de weigeringsgronden in die verordening tegen een uitvoerbaarverklaring in verzet kan worden gekomen, kan een belanghebbende onder de Brussel I Herschikking evenzeer om weigering van erkenning of tenuitvoerlegging verzoeken. Artikel 45 Brussel I Herschikking geeft daarvoor een vijftal gronden. Een van die gronden zegt dat een erkenning wordt geweigerd indien 'het stuk dat het geding inleidt of een gelijkwaardig stuk niet zo tijdig en op zodanige wijze is betekend aan de verweerder tegen wie verstek werd verleend, als met het oog op zijn verdediging nodig was, tenzij de verweerder tegen de beslissing geen rechtsmiddel heeft aangewend terwijl hij daartoe in staat was'. Deze grond staat in Avotinšs/Letland centraal, hoewel het daar gaat om artikel 34 (2) Brussel I Verordening, maar de bewoordingen van deze oude bepaling zijn gelijk aan de weigeringsgrond in de herschikte verordening. Een andere, in Avotiņš/Letland niet aan de orde gestelde, maar volgens mij wel van belang zijnde weigeringsgrond betreft de kennelijke strijdigheid van de erkenning met de openbare orde van de angezochte lidstaat, als in artikel 34 (1) Brussel I Verordening en artikel 45 Brussel I Herschikking. Deze grond is pas van toepassing als geen andere weigerings-

20. Zie: European Parliamentary Research Service, Europeanisation of civil procedure. Towards common minimum standards?, 2015; Committee of Legal Affairs, Working document on establishing common minimum standards for civil procedure in the European Union - the legal basis, 2015; European Parliamentary Research Service, Common minimum standards of civil procedure. European Added Value Assessment Annex I, 2016.

21. Overweging 3 Preambule Brussel I Herschikking.

22. Overweging 3 Preambule Brussel I Herschikking.

23. Overweging 26 Preambule Brussel I Herschikking. 
grond kan worden toegepast. Ook voor deze grond geldt dat die ook reeds als zodanig in de Brussel I Verordening was opgenomen, te weten in artikel 34 (1).

Aangezien het Hof van Justitie zich nog niet heeft uitgesproken over de twee hiervoor genoemde weigeringsgronden in de Brussel I Herschikking, is het meest zinvol voor de uitleg daarvan de uitspraken van het Hof van Justitie onder de oude gronden te bezien. De beide gronden in de herschikte verordening zijn, zoals gezegd, bovendien gelijk aan de gronden in de Brussel I Verordening. Het ligt daarom voor de hand de uitspraken van het Hof van Justitie onder de oude gronden (ten minste) als vertrekpunt te nemen.

In zijn uitspraken heeft het Hof van Justitie ten aanzien van de uitleg van de weigeringsgronden vooropgesteld dat de weigeringsgronden restrictief moeten worden uitgelegd, aangezien ze in de weg staan aan het behalen van de met de verordening gestelde doelen. ${ }^{24}$ Die restrictieve uitleg moet (mede) worden bezien in het licht van de bevoegdheidsregeling, aldus het Hof van Justitie in het arrest Klomps/Michel ten aanzien van de voorganger van de Brussel I Verordening - het Verdrag van Brussel (EEX-verdrag) -, namelijk dat de bevoegdheid van de gerechten van de staat van herkomst 'rechtstreeks en nauwkeurig zijn geregeld'. ${ }^{25}$ In diezelfde uitspraak overwoog het Hof van Justitie dat het doel van de weigeringsgrond is dat een beslissing niet wordt erkend en ten uitvoer gelegd als de verweerder niet in de mogelijkheid is geweest om zichzelf te verdedigen voor het gerecht van de staat van herkomst. ${ }^{26}$

\subsubsection{Weigeringsgrond: rechten van vermeer}

De rechten van verweer worden (tegenwoordig) voldoende gerespecteerd als de verweerder 'in staat is geweest' tegen de beslissing bij verstek op te komen. ${ }^{27}$ Dat 'in staat zijn', heeft het Hof van Justitie in de zaak ASML/SEMIS verduidelijkt, moet zo worden uitgelegd dat niet een enkele formele onregelmatigheid bij de betekening aan het 'in staat zijn' in de weg staat. Het gaat erom, beslist het Hof, dat de verweerder 'kennis [moet] hebben gehad van de inhoud van die beslissing en wel zo dat hij tijdig en effectief zijn rechten geldend

24. HvJ EU 16 juli 2015, C-681/13, par. 41 (Diageo Brands/Simiramida-04). Zie ook HvJ EG 28 maart 2000, C-7/98, par. 21 (Krombach/ Bamberski); HvJ EG 11 mei 2000, C-38/98, par. 26 (Renault/Mexicar); HvJ EG 28 april 2009, C-420/07, par. 55 (Apostolides/Orams en Orams).

25. HvJ EG 16 juni 1981, C-166/80, par. 7 (Klomps/Michel).

26. HvJ EG 16 juni 1981, C-166/80, par. 9 (Klomps/Michel).

27. Oorspronkelijk besliste het Hof van Justitie in Hendrikman en Feyen/ Magenta dat een verweerder reeds vanaf de start van een procedure, oftewel van het 'het tijdstip van inleiding van het geding', in staat diende te zijn om zichzelf te verweren. Het Hof van Justitie overwoog daartoe dat 'de mogelijkheid om achteraf een rechtsmiddel aan te wenden tegen een verstekvonnis waarvoor verlof tot tenuitvoerlegging is verleend, (...) niet dezelfde waarde [heeft] als vóór die beslissing gevoerd verweer'. Die uitspraak werd echter nog gewezen onder het Verdrag van Brussel 1968 (in de literatuur ook: EEX-Verdrag). Met de passage in de opvolger van het Verdrag van Brussel, de Brussel I Verordening, dat de weigeringsgrond niet opgaat als de verweerder tegen de beslissing geen rechtsmiddel heeft aangewend terwijl hij daartoe in staat was, is aan dat uitgangspunt een einde gekomen. Zie HvJ EG 10 oktober 1996, C-78/95 (Hendrikman en Feyen/Magenta). heeft kunnen maken bij het gerecht van de staat van herkomst'. ${ }^{28}$ Met deze benadering wordt voorkomen dat een verweerder, alhoewel hij kennis heeft van de inhoud van een beslissing, vanwege een formele onregelmatigheid stil blijft zitten om ervoor te zorgen dat erkenning en tenuitvoerlegging niet kan plaatsvinden. ${ }^{29}$

De passage in artikel 34 (2) Brussel I Verordening dat de verweerder kan worden tegengeworpen dat hij tegen de beslissing van het gerecht van herkomst geen rechtsmiddel heeft aangewend terwijl hij daartoe in staat was, kwam aan de orde in de zaak Lebek/Domino. Een 'recht om te verzoeken om een nieuwe termijn voor het aanwenden van een rechtsmiddel' omdat de termijn voor het aanwenden van een rechtsmiddel reeds is verstreken, blijkt uit Lebek/Domino, moet ook worden beschouwd als een middel dat als doel heeft de rechten van de verweerder te waarborgen en is dus een rechtsmiddel in de zin van de weigeringsgrond ${ }^{30}$ Dat betekent dat van de verweerder wordt verwacht dat hij een dergelijk verzoek indient, bij nalaten waarvan hij niet met succes een beroep op de weigeringsgrond kan doen.

Het aangezochte gerecht is ten slotte bevoegd om, in de context van de beoordeling van het beroep op artikel 34 (2) Brussel I Verordening, zelfstandig (independent) te onderzoeken of de verweerder inderdaad 'de betekening of kennisgeving van het gedinginleidende stuk heeft ontvangen', en ook 'of die eventuele betekening of kennisgeving tijdig is gebeurd en op zodanige wijze als met het oog op zijn verdediging nodig was'. ${ }^{31}$ Het Hof van Justitie maakt in deze zaak (Trade Agency/Seramico Investments) aldus een belangrijke afweging tussen vertrouwen op de juistheid van hetgeen door het gerecht van herkomst in het certificaat ${ }^{32}$ is vermeld, en de ruimte die het aangezochte gerecht is gegeven om onderzoek te verrichten naar de procedure in de lidstaat van herkomst.

\subsubsection{Weigeringsgrond: openbare orde}

De weigering vanwege kennelijke strijdigheid van de erkenning met de openbare orde van de aangezochte lidstaat komt pas aan bod als geen enkele van de meer specifieke gronden van toepassing is en dient enkel in zeer uitzonderlijke gevallen te worden toegepast, zo volgt uit het arrest Hendrikman en Feyen/Magenta. ${ }^{33}$ De invulling van de strijdigheid met de openbare orde wordt in beginsel bepaald door de nationale opvattingen, maar met het voorbehoud door het Hof van Justitie dat de afbakening 'een kwestie van uitlegging van deze verordening' is en dus aan hem voorbehouden. ${ }^{34}$ Het Hof van

28. HvJ EG 14 december 2006, C-283/05, par. 47, NJ 2008/472, m.nt P. Vlas (ASML/SEMIS).

29. P. Vlas, annotatie bij HvJ EG 14 december 2006, C-283/05, NJ 2008/472 (ASML/SEMIS).

30. HvJ EU 7 juli 2016, C-70/15, par. 38 (Lebek/Domino).

31. HvJ EU 6 september 2012, C-619/10, par. 38 (Trade Agency/Seramico Investments).

32. Bedoeld is het certificaat betreffende een beslissing in burgerlijke en handelszaken in de zin van art. 54 Brussel I Verordening resp. art. 53 Brussel I Herschikking.

33. HvJ EG 10 oktober 1996, C-78/95, par. 20 (Hendrikman en Feyen/ Magenta).

34. HvJ EG 28 maart 2000, C-7/98, par. 22 (Krombach/Bamberski). 
Justitie heeft voor de beoordeling van de kennelijke strijdigheid in Krombach/Bamberski en Renault onder het Verdrag van Brussel de volgende maatstaf gegeven:

'Er kan enkel een beroep worden gedaan op de openbare-ordeclausule van artikel 27, punt 1 , Executieverdrag, indien de erkenning of tenuitvoerlegging van de in een andere verdragsluitende staat gegeven beslissing op onaanvaardbare wijze zou botsen met de rechtsorde van de aangezochte staat, doordat inbreuk op een fundamenteel beginsel zou worden gemaakt. Opdat het verbod van onderzoek van de juistheid van de in den vreemde gegeven beslissing in acht wordt genomen, zou de inbreuk moeten bestaan in kennelijke schending van een rechtsregel die in de rechtsorde van de aangezochte staat van essentieel belang wordt geacht, of van een in die rechtsorde als fundamenteel erkend recht.' 35

In de zaak Apostolides/Orams en Orams heeft het Hof van Justitie bevestigd dat die maatstaf ook geldt onder de Brussel I Verordening. ${ }^{36}$

In flyLAL-Lithuanian Airlines/Starptautiskā lidosta Rīga and Air Baltic Corporation overwoog het Hof van Justitie dat het openbare-ordebegrip dient 'ter bescherming van rechtsbelangen die in een rechtsregel tot uitdrukking komen, en niet van zuiver economische belangen'. ${ }^{37}$ In die zaak werd, kort gezegd, erkenning en tenuitvoerlegging gevorderd van een uitgesproken beslaglegging op roerende en/of onroerende zaken voor een bedrag van meer dan 58.000.000 euro, die was uitgesproken in het kader van een procedure waarin vergoeding werd gevorderd vanwege misbruik van de machtspositie en mededingingbeperkende maatregelen. Onder verwijzing naar Apostolides/Orams en Orams overwoog het Hof van Justitie nog dat aldus 'enkel een beroep [kan] worden gedaan op de openbare-ordeclausule (...), indien de erkenning of de tenuitvoerlegging van de in een andere lidstaat gegeven beslissing op onaanvaardbare wijze zou botsen met de rechtsorde van de aangezochte staat doordat inbreuk op een fundamenteel beginsel zou worden gemaakt. Het verbod om de juistheid van de in een andere lidstaat gegeven beslissing te onderzoeken wordt dus enkel in acht genomen indien de inbreuk bestaat in kennelijke schending van een rechtsregel die in de rechtsorde van de aangezochte staat van essentieel belang wordt geacht, of van een in die rechtsorde als fundamenteel erkend recht.' 38

Deze maatstaf gaat evengoed op als voor het aangezochte gerecht wordt geklaagd over een onjuiste toepassing van Unierecht. Een dergelijk situatie deed zich voor voor de Nederlandse rechter in de meer recente zaak

35. HvJ EG 28 maart 2000, C-7/98, par. 37 (Krombach/Bamberski); HvJ EC 11 mei 2000, C-38/98, par. 30 (Renault/Mexicar).

36. HvJ EG 28 april 2009, C-420/07, par. 59 (Apostolides/Orams en Orams).

37. HvJ EU 23 oktober 2014, C-302/13, par. 47 (flyLAL-Lithuanian Airlines/Starptautiskā lidosta Rīga and Air Baltic Corporation).

38. HvJ EU 23 oktober 2014, C-302/13, par. 49 (flyLAL-Lithuanian Airlines/Starptautiskā lidosta Rīga and Air Baltic Corporation).
Diageo Brands/Simiramida-04. ${ }^{39}$ In die zaak vorderde Simiramida (gevestigd in Bulgarije) vergoeding van schade geleden door onrechtmatige inbeslagname van een partij whisky door het Nederlandse Diageo Brands. Simiramida baseerde die vordering op een uitspraak van de Bulgaarse rechter dat de import van Johnny Walker whisky door Simiramida zonder toestemming van de houdster van het merk, Diageo Brands, geen merkinbreuk opleverde. Diageo betoogde voor de Nederlandse rechter, met een beroep op de openbare-ordeclausule, dat de Bulgaarse uitspraak door de Nederlandse rechter niet kon worden erkend, omdat de Bulgaarse rechter het Unierecht kennelijk onjuist zou hebben toegepast en ten onrechte geen prejudiciële vraag aan het Hof van Justitie zou hebben voorgelegd. ${ }^{40}$ In antwoord op vragen die door de Hoge Raad aan het Hof van Justitie werden gesteld, besliste het Hof van Justitie (onder meer) dat de openbare-ordeclausule 'enkel [kan] worden toegepast wanneer deze onjuiste rechtsopvatting inhoudt dat de erkenning van de betrokken beslissing in de aangezochte staat de kennelijke schending van een fundamentele rechtsregel in de rechtsorde van de Unie en dus van deze lidstaat zou opleveren'. ${ }^{41}$ Uit Diageo Brands/Simiramida-04 kan tot slot (onder meer) worden afgeleid dat bij strijdigheid met de openbare orde zowel kan worden gedacht aan de schending van een materieel recht als aan de schending van een procedurele waarborg. ${ }^{42}$

Een laatste hier te noemen interpretatie door het Hof van Justitie is gegeven in de in de vorige paragraaf ook genoemde zaak Trade Agency/Seramico Investments. Een van de vragen in die zaak ziet op de situatie waarin het gerecht van herkomst bij verstek een beslissing heeft uitgesproken zonder dat 'het voorwerp, de gronden en de gegrondheid van de vordering zijn onderzocht'. Het is de vraag of dat houdbaar is in het licht van het recht op een eerlijk proces zoals wordt bedoeld in artikel 6 EVRM en artikel 47 EU Handvest. Het Hof van Justitie overweegt dat in een dergelijk geval inderdaad kan worden gesproken van een beperking van het recht op een eerlijke proces, maar dat beperkingen onder omstandigheden kunnen worden gerechtvaardigd, namelijk 'op voorwaarde dat (...) [de beperkingen] daadwerkelijk beantwoorden aan doelstellingen van algemeen belang die door de betrokken maatregelen worden nagestreefd en niet, gelet op het nagestreefde doel, een kennelijke en buitensporige inbreuk op de aldus gewaarborgde rechten vormen'. ${ }^{43}$

Belangrijk was dat in de voorliggende zaak de staat van herkomst (Verenigd Koninkrijk) heeft uitgelegd dat zo'n verstekbeslissing alleen kan worden gegeven als in het verzoekschrift en 'een gedetailleerde uiteenzetting van de conclusies' (de zogenoemde particulars of claim) een
39. HvJ EU 17 juli 2015, C-681/13 (Diageo Brands/Simiramida-04)

40. HvJ EU 17 juli 2015, C-681/13 (Diageo Brands/Simiramida-04)

41. HvJ EU 17 juli 2015, C-681/13, par. 50 (Diageo Brands/Simiramida-04).

42. HvJ EG 28 april 2009, C-420/07, par. 46 e.v. (Apostolides/Orams en Orams).

43. HvJ EU 6 september 2012, C-619/10, par. 55 (Trade Agency/Seramico Investments). 
uitgebreide uiteenzetting wordt gegeven van feiten en gronden waarop de vordering berust. En dat bovendien de verweerder herhaaldelijk in kennis is gesteld van de tegen hem ingestelde vordering, maar niets heeft ondernomen om daartegen in verweer te komen. De verstekbeslissing dient dan het doel 'een snel, efficiënt en goedkoper verloop te verzekeren van de procedures die worden ingesteld om niet-betwiste schuldvorderingen te innen'. ${ }^{44}$ Dat doel, aldus het Hof van Justitie, kan de beperking van het recht op een eerlijk proces rechtvaardigen. Maar niet zonder meer. Het Hof van Justitie overweegt nog dat het 'aan de verwijzende rechter [staat] om na te gaan of, gelet op de concrete omstandigheden van het hoofdgeding, de door het procesrecht van het Verenigd Koninkrijk ingevoerde beperking niet kennelijk onevenredig is in verhouding tot het nagestreefde doel (...)'. En ook dat de omvang van de motiveringsplicht niet steeds gelijk is, maar afhangt van 'de aard van de betrokken rechterlijke beslissing' en 'moet worden onderzocht in het licht van de procedure, in haar geheel beschouwd, en van alle relevante omstandigheden, met inachtneming van de met deze beslissing gepaard gaande procedurele waarborgen, om na te gaan of deze laatste de betrokken personen de mogelijkheid waarborgen om tegen die beslissing zinvol en effectief een rechtsmiddel aan te wenden (...)'. ${ }^{45}$

Het Hof van Justitie komt tot de conclusie dat dit in casu betekent dat de aangezochte rechter dient te onderzoeken of de verweerder kennis heeft gehad van de particulars of claim en welke rechtsmiddelen hem ten dienste stonden om tegen de beslissing op te komen. ${ }^{46}$ In deze zaak heeft het Hof van Justitie dus stilgestaan bij de verhouding tussen enerzijds de automatische erkenning en ten uitvoerlegging op grond van de Brussel I Verordening en anderzijds de bescherming van het recht op een eerlijke proces conform artikel $6 \mathrm{EVRM}$ en artikel 47 EU Handvest. Het zijn dezelfde belangen, maar dan via de band van de 'rechten van verweer'grond, die in de volgende paragrafen te bespreken recente zaak Avotiňš/Letland aan de orde waren voor de Grote Kamer van het EHRM.

\section{Avotinšs/Letland: feiten}

Op 4 mei 1999 hebben de Let Avotiņš en het Cypriotische F.H. Ltd. een akte van schuldbekentenis ondertekend. Die akte hield in dat eerstgenoemde 100.000 USD zou lenen van het Cypriotische F.H. Ltd. en dat F.H. Ltd. het bedrag, vermeerderd met rente, uiterlijk anderhalve maand later, namelijk op 30 juni 1999, zou terugontvangen. In de schuldbekentenis waren verder een forumkeuze en rechtskeuze opgenomen, zodat de

44. HvJ EU 6 september 2012, C-619/10, par. 57 (Trade Agency/Seramico Investments).

45. HvJ EU 6 september 2012, C-619/10, par. 59-60 (Trade Agency/Seramico Investments).

46. HvJ EU 6 september 2012, C-619/10, par. 61 (Trade Agency/Seramico Investments).
Cypriotische rechter niet-exclusief bevoegd was om over geschillen te oordelen en de akte werd beheerst door het Cypriotische recht. Toen F.H. Ltd. de geldsom in 2003 nog niet had terugontvangen, besloot hij Avotiňš voor de Cypriotische rechter (het Limassol District Court) te dagen. Dit was de start van een rechtsgang die uiteindelijk naar het EHRM leidde, dat op 23 mei 2016 in Grote-Kamerbezetting uitspraak heeft gedaan. ${ }^{47}$ Zoals gezegd staat die uitspraak in deze bijdrage centraal.

\section{Nationale rechtsgang, klacht voor het EHRM en uitspraak door de Grote Kamer}

\subsection{Nationale rechtsgang}

F.H. Ltd. dagvaardde Avotiňš aldus in 2003 voor de Cypriotische rechter en stelde dat Avotiňs hem de geleende 100.000 USD niet tijdig had terugbetaald. Verschillende stukken ten behoeve van de procedure zijn naar G. Street in Riga (Avotinšs' vermeende verblijfplaats) gestuurd. Daarop is geen reactie gekomen. Op 24 mei 2004 heeft de rechtbank in afwezigheid van Avotinšs uitspraak gedaan en hem veroordeeld tot terugbetaling van de geldsom, vermeerderd met rente tot het moment van betaling, en tot betaling van de kosten van geding. De uitspraak vermeldde niet welke rechtsmiddelen ertegen open zouden staan, maar wel dat Avotiňs juist was geinformeerd over de procedure. ${ }^{48}$

Op 22 februari 2005 deed F.H. Ltd. bij de rechtbank in Riga (Riga City Latgale District Court) een verzoek tot erkenning en tenuitvoerlegging van de beslissing en verzocht daarbij bovendien tot het leggen van conservatoir beslag en om een kostenveroordeling. In het verzoek werd voor Avotiňš een andere verblijfplaats dan hiervoor vermeld genoteerd, namelijk Č. Street in Riga. Die adreswijziging is een van de punten waarop het verzoek volgens de rechtbank in Riga gebrekkig is. $\mathrm{Na}$ de vaststelling dat de gebreken niet (voldoende) zijn verholpen, besliste de rechtbank het verzoek niet in behandeling te nemen. F.H. Ltd. is tegen die beslissing in beroep gegaan. De appèlrechter (Riga Regional Court) heeft de beslissing van de rechtbank verworpen, waarop de rechtbank het verzoek bij uitspraak van 27 februari 2006 alsnog volledig heeft toegewezen. ${ }^{49}$

Avotiňš raakte naar eigen zeggen niet eerder dan op 15 juni 2006 bekend met de verschillende beslissingen en wel via de deurwaarder die de Cypriotische uitspraak ten uitvoer wilde leggen. Avotiņš verzocht daarop bij de Letse rechter om de beroepstermijn in de procedure voor erkenning en tenuitvoerlegging te verlengen. Dat verzoek is ingewilligd. Het beroep, onder meer gegrond
47. EHRM (Grote Kamer) 23 mei 2016, 17502/07 (Avotiņš/Letland). Zie ook EHRM 25 februari 2014, 17502/07 (Avotinšs/Letland).

48. EHRM (Grote Kamer) 23 mei 2016, 17502/07, par. 15-20 (Avotiņ̌̌/Letland).

49. EHRM (Grote Kamer) 23 mei 2016, 17502/07, par. 21-25 (Avotiņš/Letland). 
op artikel 34 (2) Brussel I Verordening, is door de appèlrechter bovendien gegrond verklaard, maar bij uitspraak van 31 januari 2007 is het verzoek tot erkenning en tenuitvoerlegging alsnog door de hoogste Letse rechter toegewezen. Avotiňš heeft de som waartoe hij is veroordeeld betaald en het beslag is opgeheven. ${ }^{50}$

\subsection{Klacht voor het EHRM en uitspraak van de Kamer}

Avotinšs klaagt voor het EHRM over schending van het recht op een eerlijk proces conform artikel 6 EVRM door Cyprus ${ }^{51}$ en Letland. Artikel 6 EVRM waarborgt het 'recht [van een ieder] op een eerlijke en openbare behandeling van zijn zaak, binnen een redelijke termijn, door een onafhankelijk en onpartijdig gerecht dat bij de wet is ingesteld' bij het vaststellen van, onder meer, burgerlijke rechten en verplichtingen. De klacht die betrekking heeft op de Letse rechter ${ }^{52}$ houdt in dat die ten onrechte de Cypriotische beslissing heeft erkend en ten onrechte heeft bevolen tot tenuitvoerlegging van de beslissing. Ten onrechte, want met de Cypriotische beslissing zou inbreuk zijn gemaakt op zijn rechten van verweer. Op 25 februari 2014 heeft het EHRM in Kamer-bezetting beslist dat er geen schending van artikel 6 EVRM heeft plaatsgevonden. De Kamer overweegt daartoe dat eerbiediging door de Letse staat van zijn verplichtingen, voortvloeiend uit het lidmaatschap van de EU, een zaak van algemeen belang is. Dat gaat ook op voor de implementatie van de Brussel I Verordening, aldus het EHRM, zodat op de Letse staat een verplichting rustte om de Cypriotische beslissing te erkennen en snel ten uitvoer te leggen. Het EHRM overweegt verder, in lijn met de hierna te bepreken Bosphorusdoctrine, dat de bescherming van fundamentele rechten door de Europese Unie in principe gelijk is aan de bescherming zoals door het EVRM voorgeschreven. ${ }^{53}$ De Kamer komt, met vier tegen drie stemmen, tot de beslissing dat er geen sprake is geweest van een schending van artikel 6 EVRM. Avotiņš heeft daarop verzocht tot het voorleggen van zijn klacht aan de Grote Kamer, welk verzoek is toegewezen. ${ }^{54}$

50. EHRM (Grote Kamer) 23 mei 2016, 17502/07, par. 26-35 (Avotinš/Letland).

51. Avotinš klaagt dat de Cypriotische rechter heeft nagelaten hem adequaat op te roepen om voor de rechtbank te verschijnen en bovendien heeft nagelaten hem in staat te stellen tot de uitoefening van zijn rechten als verweerder. De klacht tegen Cyprus is echter verjaard, zodat die niet door het EHRM in behandeling wordt genomen.

52. Avotinš̌ klaagt ook dat de Cypriotische rechter heeft nagelaten hem adequaat op te roepen om voor de rechtbank te verschijnen en bovendien heeft nagelaten hem in staat te stellen tot de uitoefening van zijn rechten als verweerder. De klacht tegen Cyprus is echter verjaard, zodat die niet door het EHRM in behandeling wordt genomen.

53. EHRM (Grote Kamer) 23 mei 2016, 17502/07, par. 70 (Avotiņš/Letland). Zie ook EHRM (Grote Kamer) 30 juni 2005, 45036/98, par. 160-165 (Bosphorus)

54. EHRM (Grote Kamer) 23 mei 2016, 17502/07, par. 3-7 (Avotiņš/Letland).

\subsection{Uitspraak Grote Kamer}

\subsubsection{Inleidend: artikel 6 EVRM}

De Grote Kamer start haar overwegingen met de vaststelling dat niet ter discussie staat dat de uitspraak van de Cypriotische rechter betrekking had op de inhoud van een burgerlijke verplichting, te weten de betaling van een geldsom. En dat betekent dat artikel 6 EVRM hier van toepassing is. Verder stelt de Grote Kamer voorop dat haar bevoegdheid beperkt is tot het toetsen van de nakoming van verplichtingen in artikel $6 \mathrm{EVRM}$ en stelt ook uitdrukkelijk dat de interpretatie van bepalingen uit de Brussel I Verordening niet een bevoegdheid van het EHRM is. Dat is in de eerste plaats voorbehouden aan het Hof van Justitie, via de prejudiciële procedure, maar is ook een taak van alle nationale rechters, aldus het EHRM. ${ }^{55}$ Van nakoming van artikel 6 EVRM is, tot slot en algemeen gezegd, geen sprake als een beslissing tot erkenning van een vreemde uitspraak wordt genomen zonder dat de verliezende partij enige mogelijkheid (en effectief) is geboden, in de aangezochte lidstaat dan wel in de lidstaat van herkomst, om te klagen over de onrechtvaardigheid van de procedure die tot de uitspraak heeft geleid. ${ }^{56}$

\subsubsection{De Bosphorus-presumptie}

Het EHRM is hier dus betrokken in een rechtsgeding dat mede wordt beheerst door Unierecht. Voor dergelijke situaties heeft het EHRM reeds in 2005 in de zaak Bosphorus/Ierland een belangrijke overweging gedaan. ${ }^{57}$ In die zaak overwoog het EHRM, kort gezegd, dat ingeval door een verdragsstaat uitvoering wordt gegeven aan internationale verplichtingen en de verdragsstaat niet méér doet dan dat, onder omstandigheden mag worden verondersteld dat de verdragsstaat niet van zijn verplichtingen onder het EVRM afwijkt. Dat de verdragsstaat, anders gezegd, in overeenstemming met zijn verplichtingen onder het EVRM handelt. Deze presumptie is beter bekend als de Bosphorus-presumptie. Voor het aannemen van de presumptie moet worden vastgesteld dat de organisatie die de verdragsstaten in het desbetreffende geval verplichtingen oplegt, zorg draagt voor de bescherming van fundamentele rechten op een wijze die vergelijkbaar (equivalent of comparable, uitdrukkelijk niet: identical) is met de bescherming die het EVRM biedt. Het EHRM heeft dat voor de Europese Unie aangenomen in de zaak Bosphorus en, na inwerkingtreding van het Verdrag van Lissabon en daarmee het juridisch bindend worden van het Handvest van de Grondrechten van de Europese Unie, bevestigd in Michaud. ${ }^{58}$ Het gaat dan niet alleen om materiële waarborgen (substantive guarantees), maar ook om het voorzien in mechanismen om op de naleving toe te zien (mechanisms controlling their observance). De presumptie

55. EHRM (Grote Kamer) 23 mei 2016, 17502/07, par. 100 (Avotiņš/Letland).

56. EHRM (Grote Kamer) 23 mei 2016, 17502/07, par. 98 (Avotiņš/Letland).

57. EHRM 30 juni 2005, 45036/98 (Bosphorus/lerland).

58. EHRM 30 juni 2005, 45036/98, par. 159 (Bosphorus/lerland); EHRM 6 december 2012, 12323/11, par. 106 (Michaud/Frankrijk). 
blijft achterwege als de bescherming van EVRM-rechten in het licht van de omstandigheden van het desbetreffende geval kennelijk ontoereikend (manifestly deficient) is geweest. ${ }^{59}$ De presumptie doet er bovendien niet aan af dat verdragsstaten, als zij handelen zonder dat dat op grond van internationale verplichtingen is vereist, volledig verantwoordelijk zijn voor naleving van het EVRM.

\subsubsection{Voormaarden voor toepassing}

Voor de toepassing van de presumptie gelden twee voorwaarden. ${ }^{60}$ Ten eerste is vereist dat de nationale autoriteiten geen handelingsruimte (margin of manoeuv$r e)$ is gelaten. In deze zaak is aan die voorwaarde voldaan. Daarbij is in casu van belang dat aan de beslissing van de Letse rechter een verordening ten grondslag lag (dat wil zeggen de Brussel I Verordening, en niet bijvoorbeeld een richtlijn die in het algemeen aan de staten laat middelen te kiezen om het met de richtlijn beoogde doel te bereiken), alsook dat de concrete van toepassing zijnde bepaling de nationale autoriteiten geen handelingsruime liet. Het EHRM verwijst daartoe naar 'uitgebreide rechtspraak' van het Hof van Justitie waaruit zou blijken dat de staten onder artikel 34 (2) Brussel I Verordening geen beoordelingsruimte toekomt. ${ }^{61}$

De tweede voorwaarde voor toepassing van de presumptie betreft de inzet van alle mechanismen die bestaan voor toezicht op de bescherming van fundamentele rechten, waaronder bijvoorbeeld de mogelijkheid tot het stellen van prejudiciële vragen aan het Hof van Justitie.

Of aan de voorwaarde is voldaan, moet worden beoordeeld in het licht van de omstandigheden van het concrete geval. ${ }^{62}$ Het is uitdrukkelijk geen algemene regel dat de mogelijkheid om een prejudiciële vraag te stellen aan het Hof van Justitie moet zijn benut. ${ }^{63}$ De weigering van een verzoek om verwijzing naar het Hof van Justitie door een van de procespartijen moet wel voldoende worden gemotiveerd. In de voorliggende zaak blijkt zo'n verzoek, bijvoorbeeld om uitleg van artikel 34 (2) Brussel I Verordening in het licht van de bescherming van klagers fundamentele rechten, niet te zijn gedaan. ${ }^{64} \mathrm{Het}$ is een factor die meeweegt, maar op zichzelf niet beslissend is. ${ }^{65}$ Het EHRM komt tot de conclusie dat ook aan de tweede voorwaarde is voldaan en de presumptie dus, in beginsel, opgaat.

\subsubsection{Uitzondering: kennelijk ontoereikende maarborging}

In beginsel, want het EHRM moet dan nog vaststellen of de toepassing van de presumptie achterwege dient te

59. EHRM 30 juni 2005, 45036/98, par. 103 (Bosphorus/lerland).

60. EHRM (Grote Kamer) 23 mei 2016, 17502/07, par. 105 (Avotinš̌/Letland).

61. EHRM (Grote Kamer) 23 mei 2016, 17502/07, par. 106 (Avotiņš/Letland).

62. EHRM (Grote Kamer) 23 mei 2016, 17502/07, par. 111 (Avotinš̌/Letland).

63. EHRM (Grote Kamer) 23 mei 2016, 17502/07, par. 109 (Avotiņš/Letland).

64. Zie anders EHRM 6 december 2012, 12323/11, par. 114 (Michaud/ Frankrijk).

65. EHRM (Grote Kamer) 23 mei 2016, 17502/07, par. 111 (Avotiņ̌̌/Letland). blijven omdat de bescherming van EVRM-rechten in het licht van de omstandigheden van het desbetreffende geval kennelijk ontoereikend (manifestly deficient) is geweest. In zijn algemene opmerkingen ten aanzien van dit punt onderkent het EHRM in de eerste plaats de betekenis van mechanismen van wederzijdse erkenning en van het daaraan ten grondslag liggende beginsel van wederzijds vertrouwen voor de totstandkoming van een ruimte van vrijheid, veiligheid en recht (area of freedom, security and justice). ${ }^{66}$ De legitimiteit van de totstandkoming van zo'n ruimte doet er niet aan af dat de wijze waarop wordt geprobeerd die te bereiken niet mag leiden tot een inbreuk op fundamentele rechten van personen die bij de procedures zijn betrokken. Het EHRM komt dan aan bij het (fundamentele) punt van de afweging die in de Unierechtelijke context moet worden gemaakt tussen het (effectief) nastreven van het bereiken van de ruimte van vrijheid, veiligheid en recht enerzijds en het waarborgen van fundamentele rechten anderzijds. Het EHRM refereert in die context aan een passage in de eerdergenoemde Opinion 2/13 van het Hof van Justitie, waarin laatstgenoemd hof overwoog:

'(...)] when implementing EU law, the Member States may, under EU law, be required to presume that fundamental rights have been observed by the other Member States, so that (...), save in exceptional cases, they may not check whether that other Member State has actually, in a specific case, observed the fundamental rights guaranteed by the EU. ${ }^{97}$

Het EHRM concludeert vervolgens dat een dergelijke beperking van de toetsingsbevoegdheid van een lidstaat tot uitzonderlijke gevallen (exceptional cases) in de praktijk in strijd kan zijn met de verplichting om te verzekeren dat de bescherming van fundamentele rechten niet kennelijk ontoereikend is. Het is een overweging waarmee het EHRM, denk ik, in dialoog met het Hof van Justitie onderstreept wat de plaats en betekenis van het EVRM in deze context is. ${ }^{68}$ Terwijl het Hof van Justitie in Opinion 2/13 de bijzondere aard van het Unierecht en de overwegingen die dat noodzakelijk meebrengt verklaarde, heeft het EHRM in deze algemene overweging de beperking die het EVRM in die context stelt (nog eens) benadrukt. Het leidt het EHRM uiteindelijk naar de conclusie dat in een situatie waarin tegenover de aangezochte lidstaat een ernstige en onderbouwde klacht wordt geuit, namelijk dat er sprake is van een kennelijk ontoereikende bescherming van één of meer fundamentele rechten in de staat van herkomst, terwijl dat gebrek op grond van Unierecht niet kan worden gecorrigeerd, de aangezochte staat deze klacht niet kan verwerpen op de enkele grond dat Unierecht wordt toegepast. ${ }^{69}$ Een

66. EHRM (Grote Kamer) 23 mei 2016, 17502/07, par. 113 (Avotiņš/Letland).

67. EHRM (Grote Kamer) 23 mei 2016, 17502/07, par. 114 (Avotiņš/Letland). Zie HvJ EU 18 december 2014, Avis 2/13.

68. Zie ook T. Barkhuysen en M.L. van Emmerik in hun annotatie bij EHRM (Grote Kamer) 23 mei 2016, 17502/07, AB 2017/17, p. 123.

69. EHRM (Grote Kamer) 23 mei 2016, 17502/07, par. 116 (Avotiņš/Letland). 
correctie van zo'n gebrek lijkt evenwel zowel onder de Brussel I Verordening als onder de Brussel I Herschikking (theoretisch altijd) mogelijk, namelijk via de band van de gronden voor weigering van erkenning en tenuitvoerlegging. ${ }^{70}$ Maar onrealistisch is zo'n onmogelijkheid anderzijds toch ook niet. Biagioni wijst op de verplichting op grond van artikel 42 Brussel II bis om een beslissing tot terugkeer van een kind door een gerecht in een andere lidstaat te erkennen en ten uitvoer te leggen zonder dat verzet tegen de erkenning mogelijk is. ${ }^{71}$ Het is zeer de vraag of die bepaling, gezien deze uitspraak, voor het EHRM stand zou kunnen houden. Voor de Brussel I Verordening en de Brussel I Herschikking geldt dat het belangrijk is de gronden voor weigering van erkenning en tenuitvoerlegging zo worden toegepast dat er geen sprake is van een kennelijk ontoereikende waarborging van fundamentele rechten. Wat dat concreet betekent wordt duidelijk als het EHRM (vervolgens) toekomt aan de beoordeling van de voorliggende zaak in het licht van de maatstaf van kennelijk ontoereikende waarborging van fundamentele rechten.

In zijn beoordeling stelt het EHRM in de eerste plaats vast dat de eis op grond van artikel 34 (2) Brussel I Verordening om éérst in de staat van herkomst alle rechtsmiddelen uit te putten uit oogpunt van een goede rechtsbedeling, met het oog op de proceseconomie kan worden gerechtvaardigd. Het EHRM wijst in dit verband op de (eigen) voorwaarden voor ontvankelijkheid voor het EHRM in artikel 35 EVRM, namelijk dat alle nationale rechtsmiddelen moeten zijn uitgeput. Zo'n regel kent twee aspecten, aldus het EHRM. Dat is in de eerste plaats dat staten in de gelegenheid worden gesteld fouten in hun rechtssysteem te herstellen alvorens zij voor een internationaal orgaan kunnen worden geroepen. ${ }^{72}$ En in de tweede plaats wordt verondersteld dat er in de nationale rechtssystemen een effectief rechtsmiddel tegen een vermeende rechtsinbreuk bestaat. ${ }^{73}$

Het EHRM komt dan bij het beginsel van eerlijke procesvoering (fair hearing), dat met artikel 6 EVRM dient te worden verzekerd. Dat veronderstelt onder meer procedurele gelijkheid van partijen; partijen moeten alle in de gelegenheid zijn om hun zaak voor te dragen. ${ }^{74}$ Het beroep van Avotiňš op artikel 34 (2) Brussel I Verordening voor de Letse rechter zonder dat Avotiňš eerst op Cyprus beroep had ingesteld tegen de daar uitgesproken beslissing, doet de vraag rijzen, aldus het EHRM, of er op Cyprus in de omstandigheden van deze zaak wel een

70. Vgl. Glas en Krommendijk, die schrijven dat het EHRM 'daarmee de indruk [wekt] dat er binnen de Brussel I-verordening geen plek is voor grondrechtelijke overwegingen'. L.R. Glas en J. Krommendijk in hun annotatie bij EHRM (Grote Kamer) 23 mei 2016, 17502/07, EHRC 2016/183, nr. 11

71. Biagioni 2016, p. 594

72. EHRM (Grote Kamer) 23 mei 2016, 17502/07, par. 118 (Avotiņš/Letland).

73. EHRM (Grote Kamer) 23 mei 2016, 17502/07, par. 118 (Avotiņ̌̌/Letland).

74. EHRM (Grote Kamer) 23 mei 2016, 17502/07, par. 119 (Avotiņ̌̌/Letland). juridische remedie beschikbaar was. ${ }^{75}$ Dat gezegd hebbende, overweegt het EHRM dat de Letse rechter niet mocht volstaan met het enkel bekritiseren van Avotiňs vanwege het niet op Cyprus in beroep gaan tegen de daar uitgesproken beslissing. ${ }^{76} \mathrm{Hij}$ had moeten ingaan op de bewijslast ten aanzien van het bestaan en de beschikbaarheid van een juridische remedie. Die bewijslast is niet in het Unierecht geregeld, wat betekent dat die door nationaal recht wordt bepaald. In hun gezamenlijke concurring opinion nemen Lemmens en Briede aan dat de Letse rechter aldus volgens Lets recht mochten omgaan met Avotiňš' betoog. En toch neemt het EHRM geen schending van artikel 6 EVRM aan, wat denk ik goed te verklaren is uit de terughoudendheid die met de presumptie komt. Beslissend voor de afwijzing is dat op grond van hetgeen door de Cypriotische staat is aangevoerd, duidelijk is dat Avotiňš op Cyprus wel degelijk een remedie ter beschikking had. ${ }^{77}$ Hier doet niet aan af, aldus het EHRM, dat in de Cypriotische uitspraak de beschikbare remedies niet waren vermeld. ${ }^{78}$ Avotiňš had advies in kunnen winnen over de beschikbare remedies. Het EHRM weegt in dat verband mee, en hier komt de rol van de hoedanigheid van de partij in, dat Avotiňš beleggingsadviseur (investment consultant) van beroep was en zich dus bewust had moeten zijn van de juridische gevolgen van het ondertekenen van de schuldverklaring. ${ }^{79}$ Het EHRM concludeert, het is al gezegd, dat er geen sprake is van een schending van artikel 6 EVRM.

\section{De betekenis van Avotinš̌/ Letland voor de contractenrechtspraktijk}

Wat nu is de betekenis van de Grote-Kameruitspraak in de zaak Avotiňš/Letland voor de Nederlandse contractenrechtspraktijk? In de eerste plaats is het belangrijk te weten dat in de context van de erkenning en tenuitvoerlegging op grond van de Brussel I Verordening (en volgens mij evenzeer de Brussel I Herschikking) de Bosphorus-presumptie opgaat en dat betekent: als uitgangspunt geldt dat bescherming van fundamentele rechten op vergelijkbare wijze is gewaarborgd, wat meebrengt dat het EHRM terughoudend is in de beoordeling of sprake is van een schending van één of meer EVRMrechten. Hier geldt dus dat het Unierecht vooropgaat. Het EHRM heeft daarbij wel een grens gesteld. Dat is de uit Bosphorus bekende kennelijk ontoereikende

EHRM (Grote Kamer) 23 mei 2016, 17502/07, par. 121 (Avotinš/Letland).

76. EHRM (Grote Kamer) 23 mei 2016, 17502/07, par. 121 (Avotiņš/Letland).

77. EHRM (Grote Kamer) 23 mei 2016, 17502/07, par. 122 (Avotinš̌/Letland).

78. EHRM (Grote Kamer) 23 mei 2016, 17502/07, par. 123 (Avotinš̌/Letland).

79. EHRM (Grote Kamer) 23 mei 2016, 17502/07, par. 124 (Avotiņš/Letland). 
waarborging van EVRM-rechten. EU-lidstaten blijven verantwoordelijk voor zo'n schending, ook als het Unierecht hun geen mogelijkheid biedt tot herstel. In zo'n situatie ontkomen ze niet met een verwijzing naar Unierechtelijke verplichtingen aan de verantwoordelijkheid die ze hebben op grond van het EVRM. In de context van de wederzijdse erkenning en tenuitvoerlegging is er wel zo'n mogelijkheid tot herstel. In de eerste plaats moet die worden gezocht in de staat van herkomst. En indien daar geen remedie voor handen is, biedt dat het aangezochte gerecht de mogelijkheid een uitzondering te maken op de automatische erkenning en tenuitvoerlegging van een beslissing. Het leidt Biagioni tot de conclusie, en ik denk terecht, dat hier sprake is van een 'cruciaal verschil in benadering' tussen het Hof van Justitie en het EHRM. ${ }^{80}$ Terwijl het eerste hof voorstaat dat aangezochte staten voldoende bescherming van fundamentele rechten in de staat van herkomst veronderstellen, vereist het tweede hof dat staten voortdurend waakzaam blijven bij automatische erkenning en tenuitvoerlegging. Die verschillende houdingen zijn onder de Brussel I Verordening en de Brussel I Herschikking verenigbaar, ${ }^{81}$ maar, zoals Biagioni opmerkt, moeilijker als de integratie van rechtsordes verder gaat. Daarvan is bijvoorbeeld sprake, zoals in paragraaf 4.3 .4 toegelicht, in Brussel II bis.

De uitspraak leert verder dat de wederzijdse erkenning en tenuitvoerlegging op grond van het Unierecht, ook de automatische in de Brussel I Herschikking, in beginsel de toets onder artikel 6 EVRM kan doorstaan. ${ }^{82}$ Het komt aan, en echt verrassend is dat wat mij betreft niet, op de toepassing van de weigeringsgronden. Die moeten (effectief) de ruimte bieden om inbreuken op EVRMrechten af te wenden of te herstellen. Terwijl in de zaak Avotiņš/Letland de 'rechten van verweer'-grond centraal stond, blijkt uit de rechtspraak van het Hof van Justitie, toegelicht in paragraaf 2.2.3, dat in dit verband ook de openbare-orde-exceptie belangrijk kan zijn. Die grond biedt bij uitstek ruimte om vanwege de schending van fundamentele rechten (in ruime zin, dus niet enkel van art. 6 EVRM) een uitzondering te maken op de automatische erkenning en tenuitvoerlegging.

\section{Tot slot}

Op grond van de Brussel I Verordening en de Brussel I Herschikking dient een aangezochte rechter een beslissing die in een andere EU-lidstaat is uitgesproken te erkennen en ten uitvoer te leggen. De uitzonderingen op die automatische erkenning en tenuitvoerlegging zijn in de verordeningen gegeven en moeten beperkt worden uitgelegd. Tot die uitzonderingen behoren de situatie waarin rechten van verweer zijn geschonden en ook de kennelijke strijdigheid van de erkenning met de openbare orde van de aangezochte lidstaat. Die beide gronden bieden bij uitstek ruimte om beslissingen vanwege fundamentele rechtsschendingen niet te erkennen en ten uitvoer te leggen. Terwijl de eerste grond is beperkt tot de rechten van verweer die onder de reikwijdte van het recht op een eerlijk proces vallen, is de tweede grond ruimer en kunnen ook schendingen van andere rechten daaronder vallen.

In het arrest Avotiňš/Letland is de houdbaarheid van de erkenning en tenuitvoerlegging door Letland in het licht van artikel 6 EVRM in het kader van een procedure tussen Avotinšs en F.H. Ltd. aan het EHRM voorgelegd. Het EHRM had dus te oordelen over de waarborging van artikel 6 EVRM in een context die werd beheerst door Unierecht. De zaak is daarmee, zoals gezegd, de eerste voor het EHRM na Opinion 2/13, waarin de vraag opkwam of de Bosphorus-presumptie van toepassing was. Het EHRM heeft, kort gezegd, beslist dat de Bosphorus-doctrine, zoals uitgelegd in paragraaf 4.3.2, onverminderd van toepassing is en ook opgaat in de context van de erkenning en tenuitvoerlegging op grond van de Brussel I Verordening (en wat mij betreft ook de Brussel I Herschikking). Het EHRM heeft verder beslist dat EU-lidstaten ervoor moeten waken dat er sprake is van een kennelijk ontoereikende waarborging van EVRM-rechten. Daartoe bieden de uitzonderingen voor erkenning en tenuitvoerlegging in de Brussel I Verordening en de Brussel I Herschikking ruimte.
80. G. Biagioni, Avotinš̌ v. Latvia. The Uneasy Balance Between Mutual Recognition of Judgments and Protection of Fundamental Rights, European Papers 2016/1, p. 594.

81. In gelijke zin: T. Barkhuysen en M.L. van Emmerik in hun annotatie bij EHRM (Grote Kamer) 23 mei 2016, 17502/07, AB 2017/17, p. 122.

82. In gelijke zin: T. Barkhuysen en M.L. van Emmerik in hun annotatie bij EHRM (Grote Kamer) 23 mei 2016, 17502/07, AB 2017/17, p. 123. 